\title{
TEACHING PRACTICE ASSESSMENT METHODS FOR PRE- SERVICE TEACHERS IN MALAYSIAN TEACHER EDUCATION
}

\author{
Syaiful Anwar Yahya ${ }^{a}$, Rosnidar Mansor ${ }^{\text {a }}$, Mohd Hassan Abdullah ${ }^{\text {b }}$ \\ ${ }^{a}$ Fakulti Pendidikan dan Pembangunan Manusia, Universiti Pendidikan Sultan Idris, 35900 Tanjung Malim, Malaysia \\ ${ }^{\mathrm{b}}$ Fakulti Muzik dan Seni Persembahan, Universiti Pendidikan Sultan Idris, 35900 Tanjung Malim, Malaysia \\ Corresponding e-mail: aysyaiful@yes.my
}

\begin{abstract}
The Malaysian education system has expanded from strength to strength in the last few years. Throughout last decade, the system has made significant changes from the pre-school education to the higher education. However, the quality of Malaysian teacher has always been subjected to debate since this new millennium. The main focus of this study is to identify the assessment methods that have been practiced by Malaysian teacher training institutions during teaching practice placements. This research has adopted a qualitative approach, in particular, document analysis. It was done in several phases by using purposive sampling according to some criteria that had been established. The data analysis revealed that there were five types of assessment methods has been used to evaluate pre-service teachers during teaching practice in Malaysian teacher education. In light of the findings of the study, we recommend that teacher education in Malaysia should revise the methods of teaching practice assessment for pre-service teachers to stay relevant in the context of 21 st-century education.
\end{abstract}

Keywords: Teaching Practice Assessment, Teaching Practicum, Teacher Education, Malaysia Education Model

\section{INTRODUCTION}

Throughout last decade, the Malaysian education system has made significant changes from the preschool education to the higher education. In 2013, the Ministry of Education Malaysia launched Malaysia Education Blueprint 2013-2025 that is targeted to enhance the quality of Malaysian Education that would be compatible with the invested budget every year, which includes a comprehensive transformation program for the system and key changes to the Ministry. The Malaysia Education Blueprint 20132025 that has been launched is very crucial to prepare the Malaysian education landscape toward challenging 21 st-century education.

A few strategies have been implemented to transform teaching into the profession of choice. The measures taken include raising and enforcing entry standards into teacher training programs as well as improving the effectiveness of pre-service and continuous professional development. When these strategies were used, there were many discussions regarding the teachers' quality. Ministry of Education Malaysia (2013) reported that during an observation done in $2011,50 \%$ of the classes that were observed had been deemed as unsatisfactory. They could not engage the students adequately and depend solely on passive lecture format of content delivery through the teacher. Ministry of Education Malaysia (2013) also stated that only $63 \%$ of schools who rated themselves as having Good or Excellent teaching and learning practices while the school inspector or Jemaah Nazir dan Jaminan Kualiti rated only 13\% of these schools are in the Good or Excellent teaching.

Considering this teachers' quality report, Ministry of Education has taken a few steps to counter the issue which includes stringent admission requirement for the Institute of Teacher Education intake (Ministry of Education Malaysia, 2014). This step is crucial in increasing the quality of teacher as Goh \& Blake (2015) suggested that there is a need to change the teacher preparation in Malaysia to produce more quality teacher. However, Ministry of Higher Education Malaysia (2012) suggested that to generate the quality teacher; it involves not only proper selection procedures of pre-service teachers but also a suitable curriculum, teaching approaches and assessment methods inside their training programs. 
To produce a quality teacher, there is a need to improve teacher clinical experience because it enables pre-service teachers to integrate theory and practice in a manner that allows them to be capable in making decisions to satisfy the diverse needs of their students (Darling-Hammond, 2014). The quality of Malaysian teacher has always been subjected to debate since this new millennium. Ministry of Education Malaysia has started to address this problem by introducing a more comprehensive Malaysian Education Blueprint 2013-2015 in 2013 which includes several measures to improve the quality of the teacher. Some of the steps that will be taken to improve teacher quality are to raise the entry bar for teacher education program, to revamp the Malaysian Teacher Training Institution to worldclass standards by 2020 , to enhance pathways for teachers for leadership, master teaching, and subject specialist roles and also to develop a peer-led culture of excellence and certification process.

Ministry of Higher Education Malaysia (2012) also has suggested that to produce a quality teacher; we need to go through the curriculum, teaching approaches and assessment method rather than only raising the standard of entry into the teacher education program. Therefore, there is an urgency to improve teacher clinical experience, especially in Malaysia higher education institution as suggested by Goh \& Blake (2015), which is to develop and situate teacher preparation in the schools rather than sending the unprepared pre-service teacher into the practicum. The use of teacher observation as the primary instrument to assess the teaching practicum has drawn some criticism because of the nature of the observation itself.

Teacher training institution in Malaysia is managed by the 27 Teacher Education Institutes of Malaysia (IPGM) as well as public universities (IPTA) and private universities (IPTS) (Wong, Mohd. Hassan Abdullah, Rosnidar Mansor, \& Syakirah Samsudin, 2014, p. 21). For the IPGM and public universities, the governance of the teacher preparation programs are regulated by the government which has been explained in the statement below:

In Malaysia, two bodies, the Ministry of Education and public universities are given the responsibilities of training students to become prospective teachers. Teacher education department (TED) is responsible in handling the program for the Ministry of Education while in universities, it is offered by the Faculty of Education. (Zailani Jusoh, 2013, p. 865)

During the process of teaching practice, preservice teachers will be more sensitive to the world of the real teaching profession. They always have to prepare for receiving any duties or instructions that were given by the management of the school. During this period also, guidance and evaluation of mentor teachers and institution supervisor are required by pre-service teachers to help them, particularly in the selection of the instructional method of an effective and efficient teaching. This guidance and evaluation by mentor teachers and institution supervisor are called as clinical supervision. However, Gallant \& Mayer (2012) reported that there was no evidence that authentic forms of teacher assessment were being used during teaching practicum of the pre-service teacher in Malaysian teacher clinical experience. The article has led the researchers to identify what are the methods of assessment for teaching practice that has been implemented in local teacher training institutions in Malaysia.

\section{METHOD}

This research adopts a qualitative approach, in particular, document analysis. The main research focus is to identify the assessment methods that have been practiced by Malaysian teacher training institutions during teaching practice placements. This study was done in several phases by using purposive sampling according to a specific document selection criteria that had been established at the beginning of this study.

\subsection{Sampling}

The participants in this study were nine local universities in Malaysia that offered the bachelor degree in education. They were purposefully chosen because of their willingness to participate in this study and their co-operation given during this research. Most of the universities and teacher training institution that approached are willing to disclose their assessment documents for teaching practice for the pre-service teachers, but some of the institutions are hesitant to reveal that documents.

The selection of the sample was established according to the specific selection criteria which were:

i. Public local teacher training institutions offering bachelor degree in education

ii. There was the practical part of the teacher training program that known as teaching practice or teaching practicum as a requirement to graduate in that institutions.

The sample selection procedure was divided into two stages. The first one was the Selection of Teacher Training Institution through Malaysian Qualification Register (MQR) and the second was the stage of asking permission to acquire their teaching 
assessment instruments. These stages were conducted as described below:-

\section{First Stage: Selection of Teacher Training Institutions through Malaysian Qualification Register (MQR)}

The selection of sample was made through Malaysian Qualification Register (MQR). The MQR governed by Malaysia Qualification Agency (MQA) serving as the reference point for accredited programs by MQA. The MQR can be assessed at http://www2.mqa.gov.my/mqr/. All of the programs that approved by the MQA are categorized in the MQR database according to the National Education Code that is assigned by the MQA. The National Education Code that has selected for this research is 141 (Teaching and Training). Upon checking into the MQR database, 256 programs are currently offering a bachelor degree in education in Malaysia from various institutions. After applying the specific selection criteria that had been established earlier, only twelve institutions that can be included in the study.

Second Phase: Asking Permission to Acquire Their Teaching Practice Assessment Instrument

After all the institutions that fit into the specific selection criteria has been identified, a formal letter requesting permission to acquire their teaching practice assessment instrument was sent by the researchers to obtain their instrument for further analysis. Nine of the said institutions replied this formal request and were willing to participate in this study while another two of the institutions were reluctant to contribute their instrument and another one institution did not answer the letter. After the permission had been obtained, the researchers then proceeded to gather all the instruments for teaching practice assessment from the nine institutions that had agreed to participate in this study.

\subsection{Data Analysis}

The data were coded according to the type of assessment used to evaluate pre-service teacher during teaching practice. The analysis followed a system of skimming, reading and interpretation procedures that suggested by Bowen (2009). The process of skimming and reading was a crucial step towards grouping these instruments into clear and significant categories. Moreover, the process of skimming and reading enabled us to take into consideration all the content that is available on the instruments. After extensive analysis, the instruments were interpreted to determine what type of assessment these instruments collected were fallen in which categories of assessment.

\subsection{Trustworthiness}

To establish trustworthiness for this study, the researchers took three steps to ensure that this study is rigor and authentic. The first step of trustworthiness was the preparation of audit trail to document all the evidence from this study including the description of steps taken in the research from the start of the research project to the development and reporting of findings. The copy of this audit trail was kept by the researchers in a secure location to ensure confidentiality and safety of the participation in this study. The second measure of trustworthiness is the peer debriefing. The researchers consulted with a peer for another check outside of a designated research team. The peer debriefing ensures the interpretation of the results were unbiased and free from any assumption of the researchers. The last step of trustworthiness is member checking by employing ongoing consultation with participants for their comment on the findings. The representative from each institution was interviewed upon collection of their instrument to clarify any confusion upon analysis of the assessment instrument.

\section{FINDINGS AND DISCUSSION}

\subsection{Findings}

This section presents the results of the study. First, it presents the findings of the assessment methods that had been used by Malaysian local teacher training institution to assess pre-service teacher during teaching practice. Then, it discusses the results related the methods employed to evaluate the pre-service teachers during teaching practice. 
Table 1 Methods of Assessment for Teaching Practice in Malaysian Teacher Education

\begin{tabular}{cclc}
\hline No & Institutions & \multicolumn{1}{c}{ Assessment Methods } & Marks Percentage \\
\hline 1 & A & 1. Classroom Observation & $95 \%$ \\
& & 2. Organization of Co-Curriculum Activities & $5 \%$ \\
2 & B & 1. Classroom Observation & $90 \%$ \\
& & 2. School Orientation Program & $10 \%$ \\
3 & $\mathrm{C}$ & 1. Classroom Observation & $70 \%$ \\
& & 2. School Orientation Program & $10 \%$ \\
& & 3. Reflection Journals & $10 \%$ \\
4 & 4. School Observation & $10 \%$ \\
5 & $\mathrm{D}$ & 1. Classroom Observation & $100 \%$ \\
6 & $\mathrm{E}$ & 1. Classroom Observation & $100 \%$ \\
7 & $\mathrm{~F}$ & 1. Classroom Observation & $100 \%$ \\
9 & $\mathrm{G}$ & 1. Classroom Observation & $100 \%$ \\
& $\mathrm{H}$ & 1. Classroom Observation & $100 \%$ \\
& $\mathrm{I}$ & 1. School Orientation Program & $10 \%$ \\
\end{tabular}

Table 2 Type of Assessment Methods for Teaching Practice in Malaysian Teacher Education

\begin{tabular}{cccc}
\hline No. & $\begin{array}{c}\text { Assessment } \\
\text { Methods }\end{array}$ & $\begin{array}{c}\text { No. of } \\
\text { Institutions }\end{array}$ & Percentage \\
\hline 1. & $\begin{array}{c}\text { Classroom } \\
\text { Observation } \\
\text { School } \\
\text { Orientation } \\
\text { Program } \\
\text { School }\end{array}$ & 9 & $100.00 \%$ \\
2. Observation & 2 & $33.33 \%$ \\
3. Organisation of \\
Co-Curriculum \\
Activities
\end{tabular}

\subsection{Discussion}

The data analysis revealed that there were five types of assessment methods has been used to evaluate preservice teachers during their teaching practice. All institutions that participate in this study employed classroom observation as the main assessment methods with the percentage ranging from $70 \%$ to $100 \%$ for this method alone. School orientation program was the second methods of assessment that was chosen to evaluate pre-service teachers during teaching practice with three institutions utilizing this method with the percentage ranging from $10 \%$ to $20 \%$ followed by school observation $(22.22 \%)$, organization of co-curriculum activities $(11.11 \%)$ and reflection journal with one institution (11.11\%) specifically using this method to evaluate their preservice teachers.

\subsubsection{Classroom Observation}

Classroom observation is a series of observation with the provision of feedback by the supervisors on the classroom interactions and helps pre-service teachers teach more effectively (Glatthorn, 1984). Classroom observation is the oldest method of pre-service teachers assessment because it was developed in the 1960 's and is still the most frequent method used to evaluate pre-service teacher during teaching practice (Sullivan, 1980; Yahya, Mansor, \& Abdullah, 2017). This statement is consistent with the finding from this study where classroom observation has been employed in all participating teacher training institutions. There were a lot of arguments and criticisms for using the classroom observation as the main assessment method for teaching practice. Most of the arguments were classroom observation was not an authentic assessment because pre-service teachers tend to alter their teaching style under the observation by their supervisor and the number of observation are not significant compared to the weeks of their placement in school (Kulik, 2001; Rusznyak \& Bertram, 2015; Scriven, 1981). Despite all the criticisms, classroom observation is still an important assessment method to evaluate teaching practice, but it was over utilized as an assessment technique. Although it is sometimes argued that mentor teachers and institution supervisors unable to make appropriate and dependable assessment judgments from observations of students in natural settings, there were several rebuttals that can be concluded to improve classroom observation (Maxwell, 2001). 


\subsubsection{School Orientation Program}

School orientation program or teacher school experience is a component that introduces pre-service teacher to the schools where they will undergo the teaching practice. Most of the renowned universities in the world separate this program from teaching practice (Wong et al., 2014). According to the data in table 2, three universities still incorporate school orientation program with their teaching practice while the other universities had already omitted this program from their structure or separated school orientation program into the previous semester ahead of the teaching practice. The element of the school orientation program was only complementing the teaching practice, and the inclusion of this program is not appropriate due to different objectives of these two courses. The main objective of the teaching practice is to integrate the theory into practice and to blend into the teaching profession (DarlingHammond, 2014) while the school orientation program aims to indulge the pre-service teachers in real-life experiences of the schools through observation, inquiry and practices.

\subsubsection{School Observation}

The school observation is very imperative to provide a balanced evaluation towards the pre-service teacher's performance in the school where they were placed in teaching practice. The elements that were gauged in the school observation include the attitude of pre-service teachers, their attendance to the school, the skills that they demonstrated outside the classroom, their discipline and also their involvement in the school community and activities. There were two institutions $(22.22 \%)$ which prepared specific instruments to evaluate their pre-service teachers during the teaching practice. This instrument, however, was different from what their mentor teachers used to grade them because the mentor teachers were only focusing on the classroom observation. The use of school observation instrument is consistent with a suggestion from Merç (2015) that punctuality and attendance are critical factors during teaching practice and these elements must be evaluated for the final grade in teaching practice. Al-malki \& Weir (2014) further added that professional engagement, social, professional relationships in and outside schools also should be integrated into the assessment criteria for the preservice teacher during teaching practice.

\subsubsection{Organization of Co-Curriculum Activities}

Apart from school observation, there was also an institution $(11.11 \%)$ which specifically developed an instrument to evaluate the organization of cocurriculum activities undertaken by their pre-service teachers during the teaching practice. The cocurriculum elements being evaluated included uniformed group, clubs and societies, sports and games as well as extra-curricular. Even though only one institution that formulated specific instrument for co-curriculum activities, most of other institutions had included these elements into classroom observation instrument. This situation might disrupt the purpose of evaluating classroom teaching with other elements that more separated from the classroom teaching. The inclusion of co-curriculum activity as an element of the assessment is related to the suggestion made by Darling-Hammond \& Snyder (2000) which required that multiple sources of evidence be collected over time and in diverse contexts to evaluate pre-service teacher during teaching practice. However, the inclusion of organization in co-curriculum activities are mainly based on the aspect of teacher profession itself because there was no literature found that suggested the inclusion of co-curriculum elements.

\subsubsection{Reflection Journals}

The last method of teaching practice assessment method in Malaysian teacher education is the reflection journals. Reflection journals is a learning tool that highlights the role of self-reflection in preservice teachers' learning (Lew \& Schmidt, 2011). Self-reflection or self-assessment is the element that plays a vital impact on the pre-service teacher development. Keeping a reflection journal encourages them to foster their reflective thinking , and, thus, should be added into the assessment of a teaching practice (Al-malki \& Weir, 2014; Danielson, 2014; Newby, 2012; Queensland College of Teachers, 2012). Most teacher training institutions in Malaysia had added the reflection part in their classroom observation which enables the pre-service teachers to reflect their teaching performance for that particular lesson. However, the reflection section in the classroom observation is still insufficient and focuses on the specific teaching event only while the reflection journals enable the pre-service teachers to promote self-reflection and to learn amongst them. One institution $(11.11 \%)$ in this study assessed their pre-service teachers using reflection journals during the teaching practice.

\section{CONCLUSIONS}

Based on the findings of this study, it can be concluded that there were multiple types of assessment method that had been used to assess pre- 
service teacher during the teaching practice in Malaysian teacher education. The use of classroom observation in Malaysian teacher education is extensive and all of the institutions participating in this study has utilized this method as a primary instrument while the majority of the institutions used classroom observation as the sole method to assess their pre-service teachers during the teaching practice.

Moreover, this finding suggested that there was no evidence of using authentic assessment such as portfolio assessment, cases, an exhibition of performances or problem-based inquiries in the assessment of pre-service teacher during teaching practice by the participating institutions. However, the definitions of authentic assessment can be taken extensively to consider another type of assessment methods that exist in the Malaysian teacher education such as reflection journals, organization of cocurriculum activities as well as school observation because these methods are also authentic and can represent the real scenario during the teaching practice.

In light of the findings of the study, we recommend that teacher education in Malaysia should revise the methods of teaching practice assessment for pre-service teachers to stay relevant with the $21 \mathrm{st}$ century education. Many authentic assessments can be utilized that enable them to be more equipped with the relevant skills and knowledge that they need to be gained. Finally, we recommend that further research should be conducted to investigate the assessment methods during teaching practice to improve the preservice teachers' performance in the future.

\section{ACKNOWLEDGEMENTS}

We would like to thank the Niche Research Grant Scheme (NRGS: 2014-0001-107-82-5), funded by Ministry of Higher Education Malaysia and Sultan Idris Education University for giving us the opportunity to accomplish this research. We would also like to acknowledge the support of all those who helped to finish the research in any way at any step.

\section{REFERENCES}

Al-malki, M. A., \& Weir, K. (2014). A Comparative Analysis between the Assessment Criteria Used to Assess Graduating Teachers at Rustaq College (Oman) and Griffith University (Australia) During The Teaching Practicum. Australian Journal of Teacher Education, 39(12), 28-42.

Bowen, G. A. (2009). Document analysis as a qualitative research method. Qualitative Research Journal9, 9(2), 27-40. http://doi.org/10.3316/qrj0902027

Danielson, C. (2014). The Framework for Teaching Evaluation Instrument, 2013 Edition. Retrieved from https://www.danielsongroup.org/download/?downloa $\mathrm{d}=448$

Darling-Hammond, L. (2014). Strengthening Clinical Preparation: The Holy Grail of Teacher Education. Peabody Journal of Education, 89(4), 547-561. http://doi.org/10.1080/0161956X.2014.939009

Darling-Hammond, L., \& Snyder, J. (2000). Authentic assessment of teaching in context. Teaching and Teacher Education, 16(5-6), 523-545. http://doi.org/10.1016/S0742-051X(00)00015-9

Gallant, A., \& Mayer, D. (2012). Teacher performance assessment in teacher education: An example in Malaysia. Journal of Education for Teaching, 38(July 2015), 295-307. http://doi.org/10.1080/02607476.2012.668330

Glatthorn, A. A. (1984). Differentiated Supervision. (R. S. Brandt \& J. A. Trick, Eds.). Alexandria, Virginia: Association for Supervision and Curriculum Development.

Goh, P. S. C., \& Blake, D. (2015). Teacher preparation in Malaysia: needed changes. Teaching in Higher Education, 20(5), 469-480. http://doi.org/10.1080/13562517.2015.1020780

Guba, E. G., \& Lincoln, Y. S. (1994). Competing Paradigms in Qualitative Research. In N. K. Denzin \& Y. S. Lincoln (Eds.), Handbook of qualitative research (pp. 105-117). Thousand Oaks, CA: Sage.

Kulik, J. A. (2001). Student Ratings: Validity, Utility, and Controversy. New Directions for Institutional Research, 2001(109), 9-25. http://doi.org/10.1002/ir.1

Lew, D. N. M., \& Schmidt, H. G. (2011). Writing to learn: can reflection journals be used to promote selfreflection and learning? Higher Education Research \& Development, 30(4), 519-532. http://doi.org/10.1080/07294360.2010.512627

Maxwell, G. S. (2001). Teacher Observation in Student Assessment. Queensland, Australia. Retrieved from https://www.qcaa.qld.edu.au/downloads/publications /research_qscc_assess_report_4.pdf

Merç, A. (2015). Assessing the Performance in EFL Teaching Practicum: Student Teachers' Views. International Journal of Higher Education, 4(2), 4456. http://doi.org/10.5430/ijhe.v4n2p44

Ministry of Education Malaysia. (2013). Malaysia Education Blueprint 2013-2025. Retrieved from http://www.padu.edu.my/files/meb_bleuprint/Chapte r 5.pdf

Ministry of Education Malaysia. (2014). 2014 Annual Report. Putrajaya. Retrieved from http://www.padu.edu.my/files/annual_report/2014pdf/PADU-ENG-LoRes-Full.pdf

Ministry Of Higher Education Malaysia. (2012). Malaysian Teacher Quality: Perception By Various Stakeholders. Kuala Lumpur, Malaysia: Pearson Malaysia Sdn Bhd.

Newby, D. (2012). Supporting good practice in teacher education through the European Portfolio for Student Teachers of Languages. Innovation in Language Learning and Teaching, 6(3), 207-218. http://doi.org/10.1080/17501229.2012.725250

Queensland College of Teachers. (2012). An investigation of best practice in evidence-based assessment within 
preservice teacher education programs and other professions.

Rusznyak, L., \& Bertram, C. (2015). Knowledge and judgement for assessing student teaching: a crossinstitutional analysis of teaching practicum assessment instruments. Journal of Education, 60, 31-62.

Scriven, M. (1981). Summative teacher evaluation. In J. Millman (Ed.), Handbook of teacher evaluation (First Edit, pp. 244-271). SAGE Publications.

Sullivan, C. G. (1980). Clinical Supervision a State of The Art Review. Alexandria, Virginia: Association for Supervision and Curriculum Development.

Teacher Training Division. (2009). Malaysian Teacher Standard. Putrajaya.

Wong, Y. M., Mohd. Hassan Abdullah, -, Rosnidar Mansor, -, \& Syakirah Samsudin, -. (2014). The Analysis of UPSI Teacher Clinical Experience In Comparative Perspective and Suggestion for New Teacher Clinical Experience Structure Research Objective Structure of Teacher Clinical Experience in Different Countries Teacher Clinical Experience of the. International Journal for Innovation Education and Research, 2(211), 14-23.

Yahya, S. A., Mansor, R., \& Abdullah, M. H. (2017) Analysis of Teaching Practice Assessment Methods for Pre-Service Teachers. International Journal of Academic Research in Business and Social Sciences, 7(3), 890-903. http://doi.org/10.6007/IJARBSS/v7i3/2957

Zailani Jusoh. (2013). Teaching Practicum: Student Teachers ' Perspectives. In 3rd International Conference On Foreign Language Language And Teaching (pp. 865-874). Bangkok: Language Institute, Thammasat University. 